\begin{abstract}
AIMS AND SCOPE
AKRUAL: Jurnal Akuntansi is available for free (open access) to all readers. The articles in AKRUAL: Jurnal Akuntansi include developments and researches in Accounting literature (theoretical studies and its applications), including but not limited to: Financial Accounting, Management Accounting, Corporate Governance, Accounting Education, Ethics and Professionalism, Capital Market and Bank, Auditing, Taxes, Public Sector Accounting, Sharia Accounting, AND Accounting Information System.
\end{abstract}

\title{
PUBLICATION INFORMATION
}

AKRUAL: Jurnal Akuntansi ( $p$-ISSN 2085-9643 \& e-ISSN 2502-6380) has been published twice a year, April and October with six articles each time published (12 articles per year) by Accounting Department, Faculty of Economics, Universitas Negeri Surabaya in cooporation with Association of Certified Fraud Examiners Indonesian Chapter \#111 and Ikatan Akuntan Indonesia Kompartemen Pendidik (IAI-KAPd)

This journal has been a Directory of Open Access Journal (DOAJ 2502-6380) since 2017. This journal has been a CrossRef member (DOI 10.26740/jaj) since 2017, so that all articles published by this journal have DOI unique numbers. This journal has been abstracted and distributed by EBSCO Publishing Started from Vol 1, No 1, October 2009 to present. AKRUAL is Nationally Accredited by Kemristekdikti. The journal is classified into national's 2 nd highest cluster for reputable journal in Indonesia (Decree No: 10/E/KPT/2019)

\section{OPEN ACCESS POLICY}

This journal provides immediate open access to its content on the principle that making research freely available to the public supports a greater global exchange of knowledge. All articles published on AKRUAL are open access by following the Creative Commons: Attribution-NonCommercial 4.0 International license.

\section{AKRUAL INDEXED BY:}
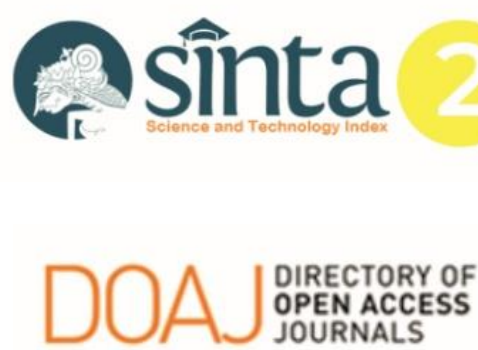
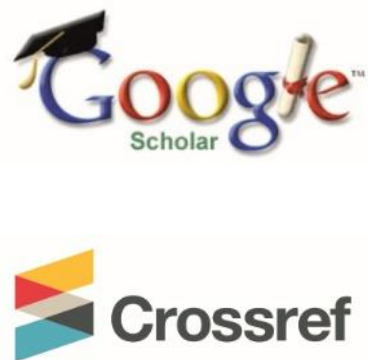


\section{AKRUAL: Jurnal Akuntansi}

ISSN (Print) 2085-9643

ISSN (online)2502-6380

DOI: dx.doi.org/10.26740/jaj

\section{EDITORIAL TEAM}

\section{EDITOR-IN-CHIEF}

Dr. Pujiono ,SE,Ak, M.Si, [SCOPUS ID:57200392519] Accounting Department, Faculty of Economics, Universitas Negeri Surabaya, Indonesia

\section{MANAGING EDITOR}

Loggar Bhilawa, SE, Ak, M.Si, CA, Accounting Department, Faculty of Economics, Universitas Negeri Surabaya, Indonesia

\section{SECTION EDITOR}

Aisyaturrahmi , SE, MA, Ak, CA, Accounting Department, Faculty of Economics, Universitas Negeri Surabaya, Indonesia

Made Dudy Satyawan, SE, Ak, M.Si, CA, Accounting Department, Faculty of Economics, Universitas Negeri Surabaya, Indonesia

Ni Nyoman Alit Triani, SE, M.Ak, Accounting Department, Faculty of Economics, Universitas Negeri Surabaya, Indonesia

\section{REVIEWERS (MITRA BESTARI)}

Dr. Dian Anita Nuswantara, Ak, M.Si, [SCOPUS ID: 57200395873] Accounting Department, Faculty of Economics, Universitas Negeri Surabaya, Indonesia

Dr. Dianwicaksih Arieftiara, SE, Ak, M.Ak, [SCOPUS ID: 57198900114] Accounting Department, Faculty of Economics and Business, UPN Veteran Jakarta, Indonesia

Dr. Tarjo, SE, M.Si, CFE, Universitas Trunojoyo Madura, Idonesia

Dr. Rohmawati Kusumaningtias, SE, Ak, MSA, Accounting Department, Faculty of Economics, Universitas Negeri Surabaya, Indonesia

Dra. Y. Anni Aryani, M.Prof.Acc., Ph.D., [SCOPUS ID: 57191042768] Accounting Department, Faculty of Economics and Business, Universitas Sebelas Maret Surakarta, Indonesia

Dr. Ida Farida Adi Prawira, SE., M.Si., Ak.,CA, Universitas Pendidikan Indonesia, Bandung, Indonesia 
AKRUAL: Jurnal Akuntansi

ISSN (Print) 2085-9643

ISSN (online) 2502-6380

DOI: dx.doi.org/10.26740/jaj

\section{TABLE OF CONTENTS}

Volume 10, Number 2, April 2019

The Investigation of Taxplayer Compliance in Tax Amnesty

$85-104$

Erlina Diamastuti, Kurniasari Novi Hardanti

The Government Auditor Professionalism Determinant

$105-118$

I Gusti Ayu Purnamawati, Ni Ketut Sari Adnyani

The Influence of Thin Capitalization and The Executives' Characteristics

$119-134$

Toward Tax Avoidance by Manufacturers Registered on Ise in 2011-2015

Dewi Prastiwi, Renni Ratnasari

Analysis of Msme Actors' Behavior in Preparing Financial Statements with

$135-144$

Modified Theory of Planned Behavior

Husnunnida Maharani

Internalization of Braya's Amazing Values as a Management of Business

$145-156$

Control in Endek Clothing Sme and Klungkung Songket (Case Study

Approach)

Ni Ketut Sari Adnyani, I Gusti Ayu Purnamawati, Ni Luh Gede Erni Sulindawati

International Financial Reporting Standard (IFRS):

$157-176$

The Awareness Level in Accounting Student

Ayu Aryista Dewi, Luh Gede Krisna Dewi 